\author{
Nadwa : Jurnal Pendidikan Islam \\ Vol. 12, Nomor 2 Tahun 2018 \\ Accredited by Ristekdikti based on Decree No. 51/E/KPT/2017
}

\title{
The Importance of Problem Based Learning in Islamic Higher Education
}

\section{Nur Kholis}

UIN Sunan Ampel Surabaya

nurkholis@uinsby.ac.id

\begin{abstract}
This article aims to explain the importance of applying the Problem Based Learning (PBL) method in Islamic Religious Colleges (PTKI). this study uses literature review. The results of the study indicate that PBL is a constructive learning method that uses problems as a trigger for the learning process. This method is important for students in Islamic higher education in constructing their own learning experiences and knowledge, to improve critical thinking skills, problem solving, train communication skills, and improve student learning outcomes.
\end{abstract}

.Keywords: Islamic Higher Education; Problem-Based Learning; metode

\begin{abstract}
Abstrak
Artikel ini bertujuan memaparkan tentang pentingnya penerapan metode Problem Based Learning (PBL) di Perguruan Tinggi Keagamaan Islam (PTKI). penelitian ini menggunakan kajian kepustakaan. Hasil penelitian menunjukkan bahwa PBL adalah metode pembelajaran konstruktivistik yang menggunakan masalah sebagai pemicu proses pembelajaran. Metode ini penting untuk mahasiswa di pendidikan tinggi Islam dalam mengkonstruk pengalaman belajar dan pengetahuan sendiri, untuk meningkatkan kemampuan berpikir kritis, pemecahan masalah, melatih keterampilan komunikasi, dan meningkatkan hasil belajar mahasiswa.
\end{abstract}

Kata Kunci: Pembelajaran Berbasis Masalah; Perguruan Tinggi Keagamaan Islam; metode

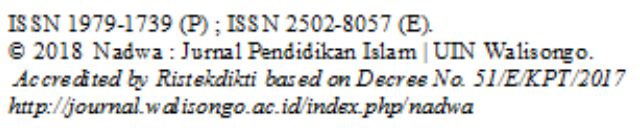




\section{Pendahuluan}

Kehadiran abad 21 telah memunculkan kompetisi global dalam berbagai bidang: ekonomi, politik, seni, pendidikan, dan bahkan agama. Persaingan bebas menyebabkan tuntutan masyarakat pada kualitas semakin tinggi.1 Lulusan lembaga pendidikan yang berkualitas akan memenangkan kompetisi itu. Kualitas lulusan yang dihasilkan oleh perguruan tinggi sangat ditentukan oleh kualitas pembelajaran yang dialami oleh mahasiswa. Oleh karena itu, peningkatan kualitas pembelajaran mahasiswa menjadi kunci sejauh mana perguruan tinggi menjaga kepuasan pelanggan dan mendapatkan respons positif dari masyarakat. Presiden RI menyerukan perlunya perubahan pola pembelajaran di perguruan tinggi menuju pembelajaran yang berkualitas yaitu pembelajaran yang sesuai dengan generasi kekinian, mendorong daya inovasi, dan menfasilitasi mahasiswa menjadi aktif baik di dalam maupun di luar kelas.2 Menteri Riset, Teknologi, dan Pendidikan Tinggi juga menegaskan pentingnya peningkatan kualitas kompetensi pembelajaran tenaga pendidik guna memperbaiki lulusan perguruan tinggi.3

Sementara ini, upaya peningkatan kualitas pembelajaran di perguruan tinggi diselesaikan dengan dorongan bahkan peraturan bagi dosen untuk mengambil pendidikan formal lanjutan, dan seiring dengan internasionalisasi pendidikan dikeluarkan kewajiban bagi dosen untuk melakukan publikasi internasional. Solusi seperti ini mengasumsikan bahwa pendidikan lanjut, penelitian, dan publikasi akan secara otomatis berdampak pada kualitas pembelajaran dosen kepada mahasiswa. Nampaknya

1 Nur Kholis, "Mencari Alternatif Formulasi Pengembangan Sistem Pendidikan Revolusioner Di Era Millenium Iii," NIZAMIA: Jurnal Pendidikan dan Pemikiran Islam 3, no. Juli-Desember (2000): hlm. 4. http://digilib.uinsby.ac.id/id/eprint/24027.

2 Mediaindonesia.com, "Presiden Minta Perguruan Tinggi Ubah Metode $\begin{array}{llll}\text { Pembelajaran," } \quad \text { accessed } & \text { Mei } & 2018 .\end{array}$ http://www.mediaindonesia.com/news/read/127626/presiden-mintaperguruan-tinggi-ubah-metode-pembelajaran/2017-10-17.

3 Ananda Teresia, "Menristekdikti Sesalkan Kualitas Lulusan Perguruan Tinggi," accessed

Mei

3 , 2018. https://kumparan.com/@kumparannews/menristekdikti-sesalkan-kualitaslulusan-perguruan-tinggi. 
asumsi ini kurang terdukung. Sinyalemen kuat menunjukkan bahwa proses pembelajaran yang dipraktekkan di perguruan tinggi pada umumnya masih berbentuk ceramah dengan ciri dosen aktif menyampaikan materi kuliah, sedangkan mahasiswa secara pasif mendengarkan kuliah dengan membuat catatan seperlunya. Pola pembelajaran seperti ini dapat menyebabkan mahasiswa belajar hanya pada kulitnya atau surface learning sebagai lawan dari deep learning, 4 dan akhirnya sulit menghasilkan lulusan yang berkualitas. Penelitian dengan metaanalisis berskala luas pada program-program sains, teknologi, teknik, dan matematika mununjukkan bahwa mahasiswa dengan metode perkuliahan ceramah memiliki kemungkinan 1, 5 kali lebih besar gagal ujian daripada mahasiswa dengan pembelajaran aktif.5 Kepuasan mahasiswa terhadap pembelajaran dengan metode kuliah juga lebih rendah dibandingkan dengan pembelajaran aktif.6

Problem-Based Learning (PBL) atau pembelajaran berbasis pemecahan masalah merupakan satu pendekatan pembelajaran yang terpusat pada mahasiswa (student-centred) diharapkan dapat meningkatkan kualitas pembelajaran mahasiswa. Dalam proses PBL mahasiswa mempelajari topik kuliah melalui pemecahan masalah dan pada umumnya bekerja kelompok untuk menyelesaikan masalah. PBL mendorong mahasiswa untuk

4 J. Biggs, "What the Student Does: Teaching for Enhanced Learning," Higher Education Research and Development 31, no. 1 (2012): hlm. 60. https://doi.org/10.1080/07294360.2012.642839. Menurut Biggs pendekatan surface learning mengacu pada aktivitas kognitif tingkat rendah dan menghasilkan capaian belajar yang tidak utuh, sedangkan pendekatan deep learning merujuk pada kegiatan-kegiatan yang tepat untuk menyelesaikan tugas sehingga hasil tercapai seraca utuh. Mendorong pendekatan deep learning sangat dianjurkan dalam pembelajaran apalagi di perguruan tinggi.

5 Scott Freeman et al., "Active Learning Increases Student Performance in Science, Engineering, and Mathematics," Proceedings of the National Academy of Sciences 111, no. 23 (2014): hlm. 8410. https://doi.org/10.1073/pnas.1319030111

6 Roya Sadeghi, Mohammad Mehdi Sedaghat, and Faramarz Sha Ahmadi, "Comparison of the Effect of Lecture and Blended Teaching Methods on Students' Learning and Satisfaction," Journal of Advances in Medical Education \& Professionalism 2, no. 4 (2014): hlm. 146. http://www.ncbi.nlm.nih.gov/pmc/articles/PMC4235559/. 
melakukan penelitian, mengintegrasikan teori dan praktik, dan menerapkan ilmu dan keterampilan untuk mengembangkan solusi atas suatu masalah yang telah ditentukan.7 Dalam PBL mahasiswa terlibat sangat aktif dalam proses pembelajaran. Beberapa penelitian menemukan dampak positif penerapan PBL dalam pembelajaran mahasiswa khususnya dalam pemecahan masalah, berpikir kritis, komunikasi, dan prestasi akademik. 8

Permasalahan terkait dengan proses dan hasil pembelajaran dan besarnya manfaat PBL dalam meningkatkan kualitas pembelajaran di perguruan tinggi mendorong penulis untuk mengkaji lebih jauh tentang PBL. Dari hasil kajian kepustakaan, dalam artikel ini, penulis membahas konsep dan model pembelajaran berbasis PBL, memaparkan dampak positif penerapan PBL, dan menawarkan strategi penerapan PBL sebagai salah satu metode pembelajaran untuk meningkatkan kualitas pembelajaran di PTKI.

\section{Hakikat Problem Based Learning}

PBL, metode pembelajaran terpusat pada mahasiswa dan bersifat konstruktivistik, dipelopori oleh dosen Kedokteran Amerika tahun 1980an, kemudian merambah ke hampir semua program studi di perguruan tinggi termasuk Arsitektur, Keperawatan, Hukum, Manajemen, dan Pendidikan.9 PBL didasarkan pada epistemologi konstruktivis yang mengasumsikan bahwa pengetahuan bersifat sementara, pengembangan, nonobjektif, dibangun secara internal, dan dimediasi secara sosial dan budaya. Menurut teori konstruktivis,

7 John R. Savery, "Overview of Problem-Based Learning: Definitions and Distinctions," Interdisciplinary Journal of Problem-Based Learning 1, no. 1 (2006): hlm. 9. https://doi.org/10.7771/1541-5015.1002.

8 Lihat misalnya, Johari Surif, Nor Hasniza Ibrahim, and Mahani Mokhtar, "Implementation of Problem Based Learning in Higher Education Institutions and Its Impact on Students' Learning" (paper presented at the PBL Across Cultures, 2013), hlm.

66. http://vbn.aau.dk/files/80390072/PBL_across_Cultures.pdf.

9 Philip Hallinger and Jiafang Lu, "Implementing Problem-Based Learning in Higher Education in Asia: Challenges, Strategies and Effect," Journal of Higher Education Policy and Management 33, no. 3 (2011): hlm. 267. https://doi.org/10.1080/1360080X.2011.565000. 
belajar adalah proses aktif yang membuat individu mengonstruk sebuah makna dan menginterpretasi situasi dari pengetahuan dan pengalaman-pengalaman sebelumnya, melalui kegiatan sosial kooperatif, wacana, dan perdebatan.10

Metode PBL berbeda dari metode pembelajaran yang hanya menyampaikan fakta dan konsep. Dalam PBL masalah nyata dimanfaatkan sebagai sarana untuk meningkatkan kualitas belajar mahasiswa tentang suatu konsep ilmu pengetahuan. Dalam kelompok, mahasiswa mengidentifiaksi apa yang telah mereka ketahui, apa yang mereka ingin ketahui, dan bagaimana serta di mana mengakses informasi baru yang memungkinkan untuk menyelesaikan masalah.11 PBL dapat mengembangkan kemampuan berpikir kritis, kemampuan pemecahan masalah, dan keterampilan komunikasi, memberikan peluang untuk kerja kelompok, serta menemukan dan mengevaluasi bahan-bahan penelitian.12 Dengan PBL, mahasiswa diharapkan mampu mengkonstruk pengalaman belajarnya dan membangun sendiri pengetahuan, sedangkan dosen berperan sebagai fasilitator atau mediator guna menciptakan proses pembelajaran yang efektif.

Prinsip-prinsip PBL. Beberapa pakar merumuskan prinsipprinsip pembelajaran PBL secara variatif. Howard Barrows13 memaparkan enam karakteristik asal model PBL yang digunakan di sekolah kedokteran: a) belajar berpusat pada mahasiswa, b) pembelajaran terjadi dalam kelompok kecil, c) dosen adalah fasilitator atau pemandu, d) masalah membentuk fokus dan stimulus asli untuk belajar, e) masalah adalah kendaraan untuk pengembangan keterampilan pemecahan masalah, dan f)

10 Catherine Twomey Fosnot and Randall Stewart Perry, "Constructivisim: A Psychologocal Theory of Learning," in Constructivism: Theory, Perspectives, and Practice, ed. Catherine Twomey Fosnot (New York: Teachers College Press, 2005), hlm. 28.

11 SIU School of Medicine, "Innovations," accessed 19 Mei, 2018. https://www.siumed.edu/dme/innovations.html.

12 Barbara J. Duch, Susan E. Groh, and Deborah E. Allen, The Power of Problem-Based Learning : A Practical "How to" for Teaching Undergraduate Courses in Any Discipline, 1st ed. (Sterling, Va.: Stylus Pub., 2001), hlm. 45 .

13 Howard S Barrows, "Problem-Based Learning in Medicine and Beyond: A Brief Overview," New Directions for Teaching and Learning, no. 68 (1996): hlm. 4. https://doi.org/10.1002/tl.37219966804. 
informasi baru diperoleh melalui belajar mandiri. Kemudian Savery dan Duffy14 merumuskan pinsip-prinsip PBL lebih rinci, mencakup 1) permasalahan menjadi starting point dalam belajar, 2) permasalahan terkait dunia nyata yang tidak terstruktur, 3) permasalahan membutuhkan perspektif ganda, 4) permasalahan menantang pengetahuan, 5) menekankan belajar mandiri, 6) pemanfaatan sumber pengetahuan yang beragam, 7) proses belajar kolaboratif, komunikatif, dan kooperatif, dan 8) pengembangan keterampilan inquiry dan pemecahan masalah sama-sama pentingnya.

Sedangkan De Graaf dan Kolmos, 15 setelah mereviu literatur yang berhubungan dengan teori-teori belajar dan praktik-praktik PBL, merumuskan tujuh prinsip-prinsip mendasar PBL: 1) masalah sebagai titik awal proses pembelajaran, 2) masalah dirumuskan oleh dosen atau mahasiswa, 3) mahasiswa membangun pengalaman dan pengetahuan sendiri (experiential learning), 4) belajar melalui kegiatan penelitian, pembuatan keputusan, dan penulisan (activity-based learning), 5) solusi masalah dapat bersumber dari berbagai ilmu pengetahuan (interdisiplin), 6) mahasiswa harus memperoleh kemampuan untuk mentransfer pengetahuan, teori, dan metode dari sebelumnya pada pengetahuan yang baru, dan 7) proses belajar terjadi dalam kelompok atau tim (group-based learning).

Inti dari beberapa rumusan tentang prinsip belajar dalam PBL di atas adalah bahwa: 1) masalah dijadikan pijakan awal dalam pembelajaran, 2) dalam memecahkan masalah diharuskan menggunakan berbagai sumber belajar dan integrasi berbagai ilmu, 3) proses belajar bersifat kolaboratif, kooperatif, dan komunikatif, 4) mahasiswa diharuskan berpikir kritis dan kreatif untuk menyelesaikan masalah, 5) pembelajaran harus mendorong refleksi dari solusi yang dirumuskan dan

14 John R Savery and Thomas M Duffy, "Problem Based Learning: An Instructional Model and Its Constructivist Framework," Educational Technology 35, no. 5 (1995): hlm. 3-6.

15 Erik De Graaf and Anette Kolmos, "Characteristics of Problem-Based Learning," International Journal of Engineering Education 19, no. 5 (2003): hlm. 658. https://www.ijee.ie/articles/Vol19-5/IJEE1450.pdf. 
mengembangkan kemampuan metokognisi, dan 6) dosen berperan utama sebagai fasilitator dalam pembelajaran.

Ciri masalah. Menurut kamus Cambridge, 16 problem (masalah) adalah situsi, orang, atau sesuatu yang membutuhkan perhatian dan perlu untuk ditangani atau dipecahkan. Secara umum suatu masalah dapat didefinisikan sebagai situasi yang memunculkan keraguan atau kesulitan dalam mencapainya.17 Suatu masalah yang digunakan dalam PBL ditetapkan berdasarkan tingkat kesulitan, adanya ragam penyelesaian, menarik, memerlukan kerjasama, dan dikenali. Masalah yang baik harus 1) merupakan simulasi kehidupan nyata, 2) menyebabkan elaborasi, 3) mendorong integrasi ilmu, 4) mendorong belajar mandiri, 5) sesuai dengan pengetahuan mahasiswa, 6) menarik bagi mahasiswa, dan 7) merefleksikan tujuan dosen. 18

Menurut Jamaludin, dkk.19 rumusan masalah yang efektif dalam PBL harus memenuhi lima kriteria mendasar. Pertama, masalah harus autentik dan realistik yakni mewakili praktik nyata dalam tempat kerja. Kedua, masalah harus dirancang sedemikian rupa sehingga mahasiswa harus aktif memanfaatkan pengetahuan sebelumnya, memahami pengetahuan baru secara mendalam, dan memperkuat dan/atau mengembangkan keterampilan tertentu (konstruktif dan integrative). Ketiga, ukuran dan kompleksitas masalah harus sesuai dengan kemampuan mahasiswa untuk memecahkannya secara kooperatif sebagai sebuah tim (kompleks tapi tidak terlalu sederhana). Keempat, masalah harus mendorong belajar mandiri dan belajar seumur hidup. Masalah otentik dan

16 Dictionary.cambridge.org, "Problem," accessed 7 Mei 2018. https://dictionary.cambridge.org/dictionary/english/problem.

17 ITS Education Asia, "What Are Problems?," accessed May 5, 2018. http://www.itseducation.asia/What-are-problems.htm.

18 Nachamma Sockalingam and Henk G Schmidt, "Characteristics of Problems for Problem-Based Learning: The Students' Perspective," Interdisciplinary Journal of Problem-based Learning 5, no. 1 (2011): hlm. 2328. https://doi.org/10.7771/1541-5015.1135.

19 Mohammad Zamry Jamaludin et al., "Crafting Engineering Problems for Problem-Based Learning Curriculum," Procedia-Social and Behavioral $\begin{array}{lllll}\text { Sciences } & 56 & \text { (2012): } & \text { hlm. } & 386-87 .\end{array}$ https://doi.org/10.1016/j.sbspro.2012.09.666. 
provokatif dapat menciptakan minat dan memotivasi mahasiswa untuk menjadi mandiri dan pebelajar seumur hidup. Ketika menghadapi masalah mahasiswa akan mencari informasi lebih lanjut, menjelajah analisis lebih lanjut, merumuskan solusi alternatif, dan membuat keputusan untuk memilih solusi terbaik untuk masalah ini.

Kelima, masalah harus merangsang pemikiran kritis dan keterampilan metakognitif. Mahasiswa harus menggunakan pemikiran kritis dalam menginterpretasikan masalah dari perspektif yang berbeda, mengidentifikasi pengetahuan yang ada dan baru, mencari dan belajar pengetahuan baru secara kooperatif untuk mencapai pemahaman yang mendalam, mengidentifikasi dan mengevaluasi solusi yang mungkin, membuat keputusan dan menerapkan konsep pengetahuan dengan benar untuk mensintesis solusi atas masalah. Di samping itu, desain masalah harus memungkinkan penyelidikan bebas dimana mahasiswa sendiri harus mengidentifikasi dan memperoleh data yang dibutuhkan untuk memecahkan masalah.

Meskipun namanya masalah, metode PBL tidak hanya mengembangkan keterampilan pemecahan masalah, tetapi membantu mahasiswa memperoleh pengetahuan berdasarkan masalah yang dihadapi dalam kehidupan sehari-hari, mengembangkan keterampilan dan sikap positif termasuk kerja tim dan keterampilan belajar-mandiri, beretika dan menghormati gagasan orang lain.

Siklus atau langkah PBL. Meskipun terdapat variasi siklus PBL yang dapat diterapkan di perguruan tinggi,20 pada umumnya PBL dijalankan dengan enam langkah. Pertama, memberikan orientasi masalah kepada mahasiswa. Dosen mengeksplorasi

20 The University of Iowa, "Steps to a Problem-Based Learning Approach," Office of Teaching, Learning \& Technology, accessed 8 Mei, 2018. https://teach.its.uiowa.edu/file-resource/869; Howard S Barrows, "Problem-Based Learning (Pbl)," accessed June 16, 2015. http://www.pbli.org/pbl/; Carmen Joham and Marilyn Clarke, "Teaching Critical Management Skills: The Role of Problem-Based Learning," Teaching in Higher Education 17, no. 1 (2012). https://doi.org/10.1080/13562517.2011.590975; Surif, Ibrahim, and Mokhtar, "Implementation of Problem Based Learning in Higher Education Institutions and Its Impact on Students' Learning." 
permasalahan dengan cara mengumpulkan informasi; mempelajari konsep-konsep baru, prinsip-prinsip, dan keterampilan tentang topik yang akan diberikan kepada mahasiswa. Kedua, pembentukan kelompok kerja mahasiswa guna menyelesaikan masalah yang telah ditentukan. Ketiga, dalam kelompok mahasiswa merumuskan masalah dan memutuskan bagaimana, kapan, dan dengan siapa mereka akan melakukan penyelidikan (merumuskan desain penyelidikan). Keempat, mahasiswa melakukan penelitian. Mahasiswa menemukan sumber dan informasi yang akan membantu menciptakan argumen yang meyakinkan, kemudian membuat daftar kemungkinan tindakan dan solusi untuk masalah, merumuskan dan menguji hipotesis potensial. Kelima, mahasiswa menghadirkan dan mendukung solusi yang dipilih. Mahasiswa menyatakan dengan jelas dan mendukung kesimpulan dengan informasi dan bukti yang relevan. Keenam, penilaian dilakukan di kelas, diikuti oleh pembelajaran kelompok dan diskusi tentang kesimpulan yang diusulkan.

\section{Dampak PBL dalam Pembelajaran}

PBL memungkinkan pembelajaran di perguruan tinggi menjadi lebih berkualitas, karena memfasilitasi mahasiswa untuk merealisasikan imaginasinya, memberikan peluang untuk berpikir, mengekspresikan gagasannya, dan mendorongnya mendapatkan informasi baru.21 Pembelajaran yang berkualitas mengintegrasikan teknik-teknik pedagogis untuk meningkatkan hasil belajar mahasiswa secara maksimal,22 dan memaksimalkan mahasiswa menggunakan proses berpikir tingkat tinggi.23 Pembelajaran berkualitas mencakup beberapa dimensi termasuk

21 Esen Ersoy and Neş'e Başer, "The Effects of Problem-Based Learning Method in Higher Education on Creative Thinking," Procedia - Social and $\begin{array}{lllll}\text { Behavioral } & \text { Sciences } & 116 & \text { (2014): } & \text { hlm. }\end{array} 498$. https://doi.org/10.1016/j.sbspro.2014.01.790.

22 Fabrice Hénard and Deborah Roseveare, Fostering Quality Teaching in Higher Education: Policies and Practices: An Imhe Guide for Higher Education Institutions (OECD Institutional Management in Higher Education, 2012), hlm. 7. hlm. 58 .

23 Biggs, "What the Student Does: Teaching for Enhanced Learning," 
rancangan kurikulum dan materi ajar yang efektif, ragam lingkungan belajar (mis., panduan belajar mandiri, belajar berbasis proyek, belajar kolaboratif, percobaan, dan lain-lain), pengumpulan dan pemanfaatan umpan balik, dan penilaian hasil belajar yang efektif. Ciri-ciri pembelajaran berkualitas mencakup memberikan rangsangan intelektual, mendorong kemampuan problem solving, dan menyediakan lingkungan yang menarik dan kreatif bagi mahasiswa;24 mendorong keterlibatan mahasiswa, dan keterampilan mengajar yang memadai;25 dan mengorganisasi kelas secara baik dan variatif.26

Dampak penerapan PBL terhadap kualitas belajar mahasiswa telah diuji secara empiris dalam berbagai penelitian dengan menggunakan program studi dan matakuliah berbeda. Penelitian terhadap kemampuan akademik mahasiswa kedokteran di Canada menemukan bahwa mahasiswa dengan pembelajaran PBL mendapatkan nilai ujian jauh lebih tinggi daripada mahasiswa dengan pembelajaran selain PBL.27 Sebuah penelitian menggunakan pendekatan meta-analisis untuk mencari dampak PBL menemukan bahwa PBL berdampak sangat positif terhadap peningkatan keterampilan dan cukup positif terhadap perolehan pengetahuan.28 Penerapan PBL pada mahasiswa Teknik di universitas-universitas Mexico juga menemukan bahwa mahasiswa yang diajar dengan pendekatan PBL mendapatkan IPK jauh lebih tinggi daripada mahasiswa

24 J. Allan, K. Clarke, and M. Jopling, "Effective Teaching in Higher Education: Perceptions of First Year Students," International Journal of Teaching and Learning in Higher Education 2, no. 3 (2009): hlm. 362. http://www.isetl.org/ijtlhe/past2.cfm?v=21\&i=3.

25 Karen Maria Clarke, "Understanding Effective Teaching: Perceptions from Students, Staff and Executive Managers in a Post-1992 University" (PhD diss., University Of Wolverhampton, 2015), hlm. 114-16.

26 J. G. Delaney et al., Students' Perceptions of Effective Teaching in Higher Education (St. John's, NL: Distance Education and Learning Technologies, 2010), hlm. iii.

${ }_{27}$ P. M. Finch, "The Effect of Problem-Based Learning on the Academic Performance of Students Studying Podiatric Medicine in Ontario," Med. Educ. 33, no. 6 (1999): hlm. 411. https://www.ncbi.nlm.nih.gov/pubmed/10354316.

28 Filip Dochy et al., "Effects of Problem-Based Learning: A MetaAnalysis," Learning and Instruction 13, no. 5 (2003): hlm. 533. https://doi.org/10.1016/S0959-4752(02)00025-7. 
yang diajar dengan selain PBL.29 Penelitian dengan pendekatan systematic review menyimpulkan bahwa PBL yang diterapkan pada mahasiswa kedokteran pada saat studi mereka berdampak positif terhadap kompetensi dokter setelah lulus, utamanya pada dimensi pengetahuan dan sosial.30

Penelitian dengan mahasiswa kedokteran di Belanda menemukan bahwa lulusan yang dibelajarkan dengan kurikulum PBL lebih baik dalam tes berpikir diagnostik, hubungan interpersonal, dan kompetensi profesi medis daripada lulusan dengan kurikulum konvensional.31 Penelitian lain dengan sampel mahasiswa S1 di Hongkong menemukan bahwa dengan pembelajaran $\mathrm{PBL}$, mahasiswa mengalami peningkatan yang sangat tinggi dalam kemampuan metakognisi, mendapatkan skor jauh lebih tinggi dalam kepuasan kuliah, dan mengalami peningkatan dalan keterampilan umum.32 Penelitian pada mahasiswa Statistics menemukan bahwa PBL cenderung memperkuat pemahaman konseptual matakuliah statistik dan meningkatkan kesadaran akan makna dan manfaat kegiatan belajar.33

29 Rodrigo Polanco, Patricia Calderón, and Francisco Delgado, "Effects of a Problem- Based Learning Program on Engineering Students' Academic Achievements in a Mexican University," Innovations in Education and Teaching International 41, no. 2 (2004): $\mathrm{hlm} .145$. https://doi.org/10.1080/1470329042000208675.

30 Gerald Choon-Huat Koh et al., "The Effects of Problem-Based Learning During Medical School on Physician Competency: A Systematic Review," CMAJ : Canadian Medical Association journal = journal de l'Association medicale canadienne 178, no. 1 (2008): hlm. 40. https://doi.org/10.1503/cmaj.070565

31 Henk Schmidt, "A Review of the Evidence: Effects of Problem-Based Learning on Students and Graduates of Maastricht Medical School," Oxford Scholarship Online, accessed May 2, 2018. http//dx.doi.org/10.1093/acprof:oso/9780199583447.003.0024.

32 Kevin Downing, Flora Ning, and Kristina Shin, "Impact of ProblemBased Learning on Student Experience and Metacognitive Development," Multicultural Education \& Technology Journal 5, no. 1 (2013): hlm. 55. https://doi.org/10.1108/17504971111121928.

33 J. Leppink et al., "The Effect of Guidance in Problem-Based Learning of Statistics," Journal of Experimental Education 82, no. 3 (2014): hlm. 391. https://doi.org/10.1080/00220973.2013.813365. 
Penelitian paling mutakhir menemukan bahwa mahasiswa kimia dengan pembelajaran PBL jauh lebih memahami materi kuliah dan strukturnya daripada mahasiswa dengan pembelajaran non-PBL,34 dan bahwa PBL berdampak sangat signifikan terhadap berpikir kreatif dan cukup signifikan pada berpikir kritis mahasiswa Seni Rupa di Turki.35 Penelitian dengan konteks Indonesia menemukan hal yang sama bahwa penerapan PBL pada mata kuliah program linier meningkatkan self-efficacy dan kemampuan berpikir kritis mahasiswa lebih tinggi dibandingkan dengan mahasiswa yang mendapat pembelajaran konvensional.36

Konsistensi dampak positif PBL terhadap pembelajaran sebagaimana dipaparkan di atas dapat dijadikan sumber inspirasi untuk menerapkannya dalam pembelajaran di lingkungan PTKI.

\section{Tantangan Implementasi}

Tantangan terbesar dalam menerapkan PBL di perguruan tinggi terkait dengan sistem nilai akademik yang dicirikan dengan mengajarkan kebenaran ilmu, budaya profesi yang individualistik yang memosisikan dosen sebagai penguasa penuh atas keilmuannya dan mementingkan kepakarannya lebih daripada organisasinya, dan tradisi pembelajaran umumnya dicirikan dengan memberikan kuliah kepada mahasiswa. Kesemuanya ini telah berkembang lama, diterima, dan bahkan didukung.

Penerapan metode pembelajaran baru seperti PBL di perguruan tinggi memerlukan perubahan struktural, kurikular, dan kultural khususnya terkait dengan peran dosen dan

34 Tugce Gunter and Sibel Klnc Alpat, "The Effects of Problem-Based Learning (Pbl) on the Academic Achievement of Students Studying 'Electrochemistry'," Chemistry Education Research and Practice 18, no. 1 (2017): hlm. 78, doi: http://dx.doi.org/10.1039/C6RP00176A.

35 Kani Ulger, "The Effect of Problem-Based Learning on the Creative Thinking and Critical Thinking Disposition of Students in Visual Arts Education," Interdisciplinary Journal of Problem-Based Learning 12, no. 1 (2018). https://doi.org/10.7771/1541-5015.1649.

36 Dina Octaria and Eka Fitri Puspa Sari, "Peningkatan Self-Efficacy Mahasiswa Melalui Problem Based Learning (Pbl) Pada Mata Kuliah Program Linier," Jurnal Elemen 4, no. 1 (2018): hlm. 66. http://ejournal.hamzanwadi.ac.id/index.php/jel/article/view/496. 
mahasiswa.37 Kepemimpinan transformatif di perguruan tinggi diperlukan untuk memperlancar penerapan PBL.38 Dalam kaitannya dengan implementasi PBL, pemimpin perguruan tinggi dapat melakukan hal-hal berikut. Mereka harus berkomitmen pada perubahan dan mendesiminasi komitmen ini pada semua dosen dan meyakinkan semua pihak bahwa perubahan harus dilakukan dan memotivasi dosen untuk sampai pada perubahan itu. Pemimpin mengambil tindakan untuk menangani penolakan-penolakan dalam menerapkan perubahan. Mereka harus memiliki gagasan dan strategi menghadapi dampak dari perubahan organisasi dan manajemen dan menindaklanjutinya. Satu gagasan perlu dipertimbangkan adalah membentuk "satuan tugas" pembelajaran PBL39 di tingkat fakultas sebagai strategi awal untuk memulai, menerapkan, dan memonitor kemajuan implementasi PBL. Tekad, kesabaran, dan keuletan satuan tugas ini diperlukan untuk berhasil memromosikan penerapan PBL di seluruh kampus.

Dalam pembelajaran PBL, dosen harus perperan sebagai tutor atau fasilitator belajar, dan mahasiswa harus memiliki kesiapan untuk belajar mandiri dan tidak menunggu disuapi ilmu dari dosennya. Ciri fasilitator efektif adalah memberikan pertanyaan untuk mendorong belajar; membantu merefleksikan pengalaman yang telah dimiliki; mengamati proses dan mengontrol situasi belajar mahasiswa; memberikan tantangan pada pemikiran mahasiswa; memunculkan isu-isu yang perlu dikaji lebih lanjut; dan memberikan rangsangan, dorongan, dan

37 Luis Roberto de Camargo Ribeiro and Maria da Graça Mizukami, "An Experiment with Pbl in Higher Education as Appraised by the Teacher and Students," Interface - Comunicação, Saúde, Educação 9 (2005): hlm. 359. http://dx.doi.org/10.1590/S1414-32832005000200011

38 Peter AJ Bouhuijs, "Implementing Problem Based Learning: Why Is It So Hard?," REDU: Revista de Docencia Universitaria 9, no. 1 (2011): hlm. $21 . \quad$ http://red-u.net/redu/files/journals/1/articles/190/public/190-196-2PB.pdf.

39 Waddah Akili, "Problem-Based Learning (Pbl): How to Implement, Strategize, and Infuse Pbl in an Engineering Program?" (paper presented at the Qscience Proceedings (World Congress on Engineering Education 2013), 2014), hlm. 6-7. https://doi.org/10.5339/qproc.2014.wcee2013.2. 
menciptakan suasana belajar yang aman dan hangat.40 Tidak semua dosen memiliki pengalaman menjadi tutot/fasilitator belajar mahasiswa. Oleh karena itu dosen memerlukan pelatihan spesifik berkaitan dengan perilaku kerja dan dinamika kelompok, menjadi tutor/fasilitator yang baik, psikologi belajar kekinian, dan tentu tentang PBL itu sendiri. Pelatihan dalam bidang ini dapat dilakukan melalui konferensi, workshop atau kerja kelompok antar dosen. Pengembangan profesional dalam konteks ini akan memperkuat keinginan dan kemauan dosen menerapkan PBL.41

\section{Kesimpulan}

Untuk menghasilkan lulusan perguruan tinggi yang berkualitas pada abad 21 diperlukan proses pembelajaran yang memungkinkan mahasiswa mengaplikasikan materi kuliah, bertanggungjawab pada belajar mereka, menggunakan teknologi secara bermakna, dan bekerjasama dalam belajar. PBL merupakan metode pembelajaran berbasis konstruktivisme yang sesuai dengan tujuan pembelajaran ini. Berbagai penelitian dengan ragam pendekatan dan subyek telah mengidentifikasi dampak positif bagi pembelajaran di perguruan tinggi, seperti meningkatnya kemampuan berpikir kritis, pemecahan masalah, komunikasi, dan hasil belajar mahasiswa. Namun, masih banyak perguruan tinggi, termasuk PTKI, yang belum menjadikan PBL sebagai satu tradisi model pembelajaran. Merupakan suatu tantangan bagi dosen untuk berubah dan dengan dukungan pimpinan yang memadai, maka ada peluang luas dalam upaya meningkatkan kualitas pembelajaran di perguruan tinggi (Islam) terutama dengan metode-metode konstruktivistik seperti PBL.

40 La Trobe University, "Effective Teaching Guide: Problem Based Learning," accessed May 24, 2018. https://www.latrobe.edu.au/ltlt/resourcelibrary/sources-bk/effective-teaching-guide-problem-based-learning.

41 Tanya Rogers, "Overcoming Implementation Challenges with Problem and Project Based Learning in Advanced Technological Education Programs within Community Colleges" (PhD diss., , Northeastern University, 2014), hlm. 3 . 


\section{Referensi}

Akili, Waddah, "Problem-Based Learning (Pbl): How to Implement, Strategize, and Infuse Pbl in an Engineering Program?" (paper presented at the Qscience Proceedings (World Congress on Engineering Education 2013), 2014), hlm. 6-7. https://doi.org/10.5339/qproc.2014.wcee2013.2.

Barbara J. Duch, Susan E. Groh, and Deborah E. Allen, The Power of ProblemBased Learning : A Practical "How to" for Teaching Undergraduate Courses in Any Discipline, 1st ed. (Sterling, Va.: Stylus Pub., 2001)

Biggs, "What the Student Does: Teaching for Enhanced Learning,"

Bouhuijs,Peter AJ, "Implementing Problem Based Learning: Why Is It So Hard?," REDU: Revista de Docencia Universitaria 9, no. 1 (2011): hlm. 21. http://red-u.net/redu/files/journals/1/articles/190/public/190-196-2PB.pdf.

Clarke, Karen Maria, "Understanding Effective Teaching: Perceptions from Students, Staff and Executive Managers in a Post-1992 University" (PhD diss., University Of Wolverhampton, 2015), hlm. 114-16.

Dictionary.cambridge.org, "Problem," accessed $7 \quad$ Mei 2018. https://dictionary.cambridge.org/dictionary/english/problem.

Dina Octaria and Eka Fitri Puspa Sari, "Peningkatan Self-Efficacy Mahasiswa Melalui Problem Based Learning (Pbl) Pada Mata Kuliah Program Linier," Jurnal Elemen 4, no. 1 (2018): hlm. 66. http://ejournal.hamzanwadi.ac.id/index.php/jel/article/view/496.

Dochy, Filip et al., "Effects of Problem-Based Learning: A Meta-Analysis," Learning and Instruction 13, no. 5 (2003): hlm. 533. https://doi.org/10.1016/S0959-4752(02)00025-7.

Downing, Kevin, Flora Ning, and Kristina Shin, "Impact of Problem- Based Learning on Student Experience and Metacognitive Development," Multicultural Education \& Technology Journal 5, no. 1 (2013): hlm. 55. https://doi.org/10.1108/17504971111121928.

Ersoy, Esen and Neş'e Başer, "The Effects of Problem-Based Learning Method in Higher Education on Creative Thinking," Procedia - Social and Behavioral Sciences 116

(2014) https://doi.org/10.1016/j.sbspro.2014.01.790.

Fosnot, Catherine Twomey and Randall Stewart Perry, "Constructivisim: A Psychologocal Theory of Learning," in Constructivism: Theory, Perspectives, and Practice, ed. Catherine Twomey Fosnot (New York: Teachers College Press, 2005)

Freeman, Scott et al., "Active Learning Increases Student Performance in Science, Engineering, and Mathematics," Proceedings of the National Academy of Sciences 111, no. $23 \quad$ (2014) https://doi.org/10.1073/pnas.1319030111 
Graaf, Erik De and Anette Kolmos, "Characteristics of Problem-Based Learning," International Journal of Engineering Education 19, no. 5 (2003): hlm. 658. https://www.ijee.ie/articles/Vol19-5/IJEE1450.pdf.

Hallinger, Philip and Jiafang Lu, "Implementing Problem-Based Learning in Higher Education in Asia: Challenges, Strategies and Effect," Journal of Higher Education Policy and Management 33, no. 3 (2011): hlm. 267. https://doi.org/10.1080/1360080X.2011.565000.

Hénard, Fabrice and Deborah Roseveare, Fostering Quality Teaching in Higher Education: Policies and Practices: An Imhe Guide for Higher Education Institutions (OECD Institutional Management in Higher Education, 2012)

Howard S Barrows, "Problem-Based Learning in Medicine and Beyond: A Brief Overview," New Directions for Teaching and Learning, no. 68 (1996): hlm. 4. https://doi.org/10.1002/tl.37219966804.

ITS Education Asia, "What Are Problems?," accessed May 5, 2018. http://www.itseducation.asia/What-are-problems.htm.

J. Allan, K. Clarke, and M. Jopling, "Effective Teaching in Higher Education: Perceptions of First Year Students," International Journal of Teaching and Learning in Higher Education 2, no. 3 (2009) http://www.isetl.org/ijtlhe/past2.cfm?v=21\&i=3.

J. Biggs, "What the Student Does: Teaching for Enhanced Learning," Higher Education Research and Development 31, no. 1 (2012): hlm. 60. https://doi.org/10.1080/07294360.2012.642839. Menurut Biggs pendekatan surface learning mengacu pada aktivitas kognitif tingkat rendah dan menghasilkan capaian belajar yang tidak utuh, sedangkan pendekatan deep learning merujuk pada kegiatan-kegiatan yang tepat untuk menyelesaikan tugas sehingga hasil tercapai seraca utuh. Mendorong pendekatan deep learning sangat dianjurkan dalam pembelajaran apalagi di perguruan tinggi.

J. G. Delaney et al., Students' Perceptions of Effective Teaching in Higher Education (St. John's, NL: Distance Education and Learning Technologies, 2010)

J. Leppink et al., "The Effect of Guidance in Problem-Based Learning of Statistics," Journal of Experimental Education 82, no. 3 (2014): hlm. 391. https://doi.org/10.1080/00220973.2013.813365.

Jamaludin, Mohammad Zamry et al., "Crafting Engineering Problems for Problem-Based Learning Curriculum," Procedia-Social and Behavioral Sciences 56 (2012) https://doi.org/10.1016/j.sbspro.2012.09.666.

John R. Savery, "Overview of Problem-Based Learning: Definitions and Distinctions," Interdisciplinary Journal of Problem-Based Learning 1, no. 1 (2006): hlm. 9. https://doi.org/10.7771/1541-5015.1002.

Kani Ulger, "The Effect of Problem-Based Learning on the Creative Thinking and Critical Thinking Disposition of Students in Visual Arts Education," Interdisciplinary Journal of Problem-Based Learning 12, no. 1 (2018). https://doi.org/10.7771/1541-5015.1649. 
Kholis,Nur, "Mencari Alternatif Formulasi Pengembangan Sistem Pendidikan Revolusioner Di Era Millenium Iii," NIZAMIA: Jurnal Pendidikan dan Pemikiran Islam 3, no. Juli-Desember (2000): hlm. 4. http://digilib.uinsby.ac.id/id/eprint/24027.

Koh, Gerald Choon-Huat et al., "The Effects of Problem-Based Learning During Medical School on Physician Competency: A Systematic Review," CMAJ : Canadian Medical Association journal = journal de l'Association medicale canadienne 178, no. 1 (2008): hlm. 40. https://doi.org/10.1503/cmaj.070565

La Trobe University, "Effective Teaching Guide: Problem Based Learning," accessed May 24, 2018. https://www.latrobe.edu.au/ltlt/resourcelibrary/sources-bk/effective-teaching-guide-problem-based-learning.

Mediaindonesia.com, "Presiden Minta Perguruan Tinggi Ubah Metode Pembelajaran," $\quad$ accessed $\quad$ Mei 2018. http://www.mediaindonesia.com/news/read/127626/presiden-mintaperguruan-tinggi-ubah-metode-pembelajaran/2017-10-17.

P. M. Finch, "The Effect of Problem-Based Learning on the Academic Performance of Students Studying Podiatric Medicine in Ontario," Med. Educ. 33 , no. 6 https://www.ncbi.nlm.nih.gov/pubmed/10354316.

Polanco,Rodrigo, Patricia Calderón, and Francisco Delgado, "Effects of a Problem- Based Learning Program on Engineering Students' Academic Achievements in a Mexican University," Innovations in Education and Teaching International 41, no. 2 (2004): hlm. 145. https://doi.org/10.1080/1470329042000208675.

Ribeiro, Luis Roberto de Camargo and Maria da Graça Mizukami, "An Experiment with $\mathrm{Pbl}$ in Higher Education as Appraised by the Teacher and Students," Interface - Comunicação, Saúde, Educação 9 (2005): hlm. 359. http://dx.doi.org/10.1590/S1414-32832005000200011

Roya Sadeghi, Mohammad Mehdi Sedaghat, and Faramarz Sha Ahmadi, "Comparison of the Effect of Lecture and Blended Teaching Methods on Students' Learning and Satisfaction," Journal of Advances in Medical Education \& Professionalism 2, no. 4 (2014) http://www.ncbi.nlm.nih.gov/pmc/articles/PMC4235559/.

Savery, John R and Thomas M Duffy, "Problem Based Learning: An Instructional Model and Its Constructivist Framework," Educational Technology 35, no. 5 (1995)

Schmidt, Henk, "A Review of the Evidence: Effects of Problem-Based Learning on Students and Graduates of Maastricht Medical School," Oxford Scholarship Online, accessed May 2, 2018. http//dx.doi.org/10.1093/acprof:oso/9780199583447.003.0024.

SIU School of Medicine, "Innovations," accessed 19 Mei, 2018. https://www.siumed.edu/dme/innovations.html. 
Sockalingam, Nachamma and Henk G Schmidt, "Characteristics of Problems for Problem-Based Learning: The Students' Perspective," Interdisciplinary Journal of Problem-based Learning 5, no. 1 (2011): hlm. 23-28. https://doi.org/10.7771/1541-5015.1135.

Surif, Johari, Nor Hasniza Ibrahim, and Mahani Mokhtar, "Implementation of Problem Based Learning in Higher Education Institutions and Its Impact on Students' Learning" (paper presented at the PBL Across Cultures, 2013), hlm.

66. http://vbn.aau.dk/files/80390072/PBL_across_Cultures.pdf.

Tanya Rogers, "Overcoming Implementation Challenges with Problem and Project Based Learning in Advanced Technological Education Programs within Community Colleges" (PhD diss., , Northeastern University, 2014).

Teresia,Ananda, "Menristekdikti Sesalkan Kualitas Lulusan Perguruan Tinggi," $\begin{array}{llll}\text { accessed Mei } & \text { 3, }\end{array}$ https://kumparan.com/@kumparannews/menristekdikti-sesalkankualitas-lulusan-perguruan-tinggi.

The University of Iowa, "Steps to a Problem-Based Learning Approach," Office of Teaching, Learning \& Technology, accessed 8 Mei, 2018. https://teach.its.uiowa.edu/file-resource/869; Howard S Barrows, "Problem-Based Learning (Pbl)," accessed June 16, 2015. http://www.pbli.org/pbl/; Carmen Joham and Marilyn Clarke, "Teaching Critical Management Skills: The Role of Problem-Based Learning," Teaching in Higher Education 17, no. 1 (2012). https://doi.org/10.1080/13562517.2011.590975; Surif, Ibrahim, and Mokhtar, "Implementation of Problem Based Learning in Higher Education Institutions and Its Impact on Students' Learning."

Tugce Gunter and Sibel Klnc Alpat, "The Effects of Problem-Based Learning $(\mathrm{Pbl})$ on the Academic Achievement of Students Studying 'Electrochemistry'," Chemistry Education Research and Practice 18, no. 1 (2017): hlm. 78, doi: http://dx.doi.org/10.1039/C6RP00176A. 